\title{
The Top 50 Most Cited Articles in Cartilage Regeneration
}

\author{
Ciaran K. Mc Donald, ${ }^{1, *}$ Peter Moriarty, Manvydas Varzgalis, and Colin Murphy ${ }^{1}$
}

\begin{abstract}
The aim of this study was to identify and analyze the top 50 most cited articles in cartilage regeneration. The impact of a scientific journal can be gauged by the total number of citations it has accrued. The top 50 most cited articles involving cartilage regeneration represent the most quoted level of evidence among this new subspecialty. This study aims to identify and analyze the 50 most cited articles in cartilage regeneration. The Web of Science ${ }^{\mathrm{TM}}$ citation indexing service was utilized to determine the most frequently cited articles published after 1956 containing "cartilage regeneration" in the "topic" or "title." The 50 most cited articles were included. The number of citations, year of publication, country of article origin, article institution, journal of publication, publication format, and authorship were then calculated for each article. The span of citations ranged from 1287 to 203 citations, with a mean of 361.02 citations per article in question. The articles originated from 11 countries, with the United States contributing 34 articles, followed by Japan with 5 articles. The articles were distributed across 34 high-impact journals. Biomaterials was the journal with the highest number of publications (seven articles) followed by the Journal of Orthopaedic Research (three articles). Of the 50 articles, 2 were clinical observational studies, 47 concerned basic science, and 1 was review article. The most cited articles involving cartilage regeneration are detected in both experimental and clinical research fields. The high ratio of basic science to clinical articles reflects the infancy of this relatively new specialty and that further clinical research is required in this area.
\end{abstract}

Keywords: bibliometric; cartilage; regeneration

\section{Introduction}

The field of orthopedic surgery continues to evolve with the advent of new technology and research. Regenerative orthopedics is rapidly becoming recognized as a new subspecialty within orthopedics.

An article receives a citation when a peer references the said article. It is broadly considered that intellectual influence of an article in a given specialty can be gauged by the level of citations received by peers. The level of evidence available to clinicians can, therefore, be estimated from assessment of the top 50 most cited articles.

Bibliometric analyses have been performed previously in medical fields and other specialties within orthopedics. Authors have examined the "classic" articles in orthopedics as a whole, ${ }^{1}$ pediatric orthopedics, ${ }^{2}$ shoulder surgery, ${ }^{3}$ and spinal surgery. ${ }^{4}$ To our knowledge, this study is the first bibliometric analysis of orthopedic cartilage regeneration.

In this study, we aim to identify the most referenced articles present in this newly established field to help give us an insight into the most quoted level of evidence currently available to clinicians and scientists alike.

\section{Methodology}

The Web of Science ${ }^{\mathrm{TM}}$ citation indexing service was utilized to determine the most frequently cited articles published from 1956 to 2016 containing "cartilage regeneration" in the "topic" or "title." The U.S. National

${ }^{1}$ Department of Trauma and Orthopaedics, Galway University Hospital, Galway, Ireland.

${ }^{2}$ Department of Breast \& Endocrine Surgery, Galway University Hospital, Galway, Ireland.

*Address correspondence to: Ciaran K. Mc Donald, MRCS, MSc, MFSEM, Department of Trauma and Orthopaedics, Galway University Hospital, Newcastle Road, Galway, Ireland, E-mail: Ciarankarl@gmail.com

(c) Ciaran K. Mc Donald et al. 2017; Published by Mary Ann Liebert, Inc. This is an Open Access article distributed under the terms of the Creative Commons Attribution License, which permits unrestricted use, distribution, and reproduction in any medium, provided the original work is properly cited. 
Library of Medicine ${ }^{\circledR}$ premier life sciences database was analyzed in this search through the Ovid ${ }^{\circledR}$ MEDLINE indexing service.

After book chapters and proceedings articles were excluded from our search, 4063 results returned. The results were arranged from highest to lowest in terms of article citations and the top 50 were then taken for further assessment.

Articles were subsequently evaluated for several characteristics including authorship, article institution, the number of calculated citations, the year of publication, the country of origin of the article, name of journal, and publication type of article.

\section{Ethical Statement}

Ethical approval was not required to conduct this bibliometric review.

\section{Results}

A total of 4063 articles returned with the mentioned inclusion criteria. The most cited article received 1287 citations, with the 50th most cited article receiving 203 citations (Table 1). There was a mean of 361.02 citations per article. The articles were published between 1991 and 2016, with the highest number of publications occurring in 2002 (Table 2).

The oldest cited article was by Longaker et al. ${ }^{5}$ and was published in 1991. The newest article was published in 2011 and was written by Nayak et al. ${ }^{6}$

Table 1. Number of Citations Received per Author in Top 50 Most Cited Articles

\begin{tabular}{|c|c|c|}
\hline 1. Hollister ${ }^{10}$ & 1287 26. Moutos et al. ${ }^{32}$ & 304 \\
\hline 2. Mackay et al. ${ }^{11}$ & 755 27. Saris et al. ${ }^{33}$ & 288 \\
\hline 3. Wakitani et al. ${ }^{12}$ & 698 28. Kragl et al. ${ }^{34}$ & 285 \\
\hline 4. Hutmacher ${ }^{13}$ & 683 29. Dezawa et al. ${ }^{35}$ & 285 \\
\hline 5. Kisiday et al. $^{14}$ & 593 30. Darling and Athanasiou ${ }^{36}$ & 283 \\
\hline 6. Yoo et al. ${ }^{15}$ & 549 31. Mikos et al. ${ }^{37}$ & 279 \\
\hline 7. Bruder et al. ${ }^{7}$ & 542 32. Rose and Oreffo ${ }^{38}$ & 271 \\
\hline 8. Bruder et al. $^{8}$ & 524 33. Freyman et al. ${ }^{39}$ & 271 \\
\hline 9. $\mathrm{Mo}^{16}$ & 505 34. Yang et al. ${ }^{40}$ & 253 \\
\hline 10. Bruder et al. ${ }^{9}$ & 492 35. Tuli et al. ${ }^{41}$ & 250 \\
\hline 11. Murphy et al. ${ }^{17}$ & 445 36. Alhadlaq and $\mathrm{Mao}^{42}$ & 245 \\
\hline 12. Wakitani et al. ${ }^{18}$ & 436 37. Nayak et al. ${ }^{6}$ & 238 \\
\hline 13. Peng et al. ${ }^{19}$ & 423 38. Lacroix and Prendergast ${ }^{43}$ & 232 \\
\hline 14. Erickson et al. ${ }^{20}$ & 405 39. Almany and Seliktar ${ }^{44}$ & 226 \\
\hline 15. Kadiyala et al. ${ }^{21}$ & 383 40. Glowacki and Mizuno ${ }^{45}$ & 223 \\
\hline 16. Kim et al. ${ }^{22}$ & 374 41. Angele et al. ${ }^{46}$ & 216 \\
\hline 17. Vunjak-Novakovic et al. ${ }^{23}$ & 367 42. Nakagawa et al. ${ }^{47}$ & 214 \\
\hline 18. Li et al. $^{24}$ & 366 43. Karande et al. ${ }^{48}$ & 207 \\
\hline 19. Cima et al. ${ }^{25}$ & 365 44. Shah et al. ${ }^{49}$ & 216 \\
\hline 20. Albrecht et al. ${ }^{26}$ & 325 45. Reddi ${ }^{50}$ & 206 \\
\hline 21. Temenoff and Mikos ${ }^{27}$ & 322 46. Carter et al. ${ }^{51}$ & 206 \\
\hline 22. Caplan et al. ${ }^{28}$ & 311 47. Thein-Han and Misra ${ }^{52}$ & 205 \\
\hline 23. Yoshimura et al. ${ }^{29}$ & 305 48. Lee et al. $^{53}$ & 204 \\
\hline 24. Minasi et al. ${ }^{30}$ & 303 49. Oliveira et al. $^{54}$ & 204 \\
\hline 25. Haines-Butterick et al. ${ }^{31}$ & 289 50. Longaker et al. ${ }^{5}$ & 203 \\
\hline
\end{tabular}

Table 2. Number of Top Cited Articles Published per Named Year

\begin{tabular}{lc}
\hline Publication year & $\begin{array}{c}\text { No. of top cited } \\
\text { articles published }\end{array}$ \\
\hline 2002 & 7 \\
1998 & 6 \\
2005 & 5 \\
2006 & 4 \\
2000 & 3 \\
2001 & 3 \\
2003 & 3 \\
2004 & 3 \\
2007 & 3 \\
1991 & 3 \\
1997 & 2 \\
2008 & 2 \\
2009 & 2 \\
2010 & 2 \\
1994 & 2 \\
2095 & 1 \\
\end{tabular}

The top 50 articles originated from 11 countries, with the United States contributing 34 articles, followed by Japan with 5 articles (Table 3 ).

The top three institutions responsible for the top cited articles all came from the United States, with Case Western Reserve University (6), Harvard University (6), and Osiris Therapeutics Inc. (4) topping the list (Table 4).

The top 50 cited articles were published in 34 high impact journals with Biomaterials (7), Journal of Orthopaedic Research (3), and Tissue Engineering (3) topping the list (Table 5).

Of the 50 articles, 2 were clinical observational studies, 46 concerned basic science, and 1 was a review article. Of the 46 basic science articles, 19 concerned the principle of tissue engineering, whereas the remaining 28 concerned cellular biology.

A total of 17 authors published two or more of the top cited articles with Bruder et al. ${ }^{7-9}$ involved as coauthor in four of the top cited articles (Table 6).

Table 3. Number of Top Cited Articles Published per Country of Origin

\section{Country of origin}

No. of top cited journals

United States

Japan

Singapore

Italy

England

Germany

Israel

The Netherlands

Portugal

Republic of Ireland
5

1

of Ireland


Table 4. Institution with Two or More of the Top Cited Articles

\begin{tabular}{lc}
\hline Institution & Number of top cited articles \\
\hline Case Western Reserve University & 6 \\
Harvard University & 6 \\
Osiris Therapeutics Inc. & 6 \\
Brigham Women's Hospital & 3 \\
Massachusetts Institute of Technology & 3 \\
National University of Singapore & 3 \\
Rice University & 3 \\
Columbia University & 2 \\
Duke University & 2 \\
Osaka Minami National Hospital & 2 \\
Tufts University & 2 \\
University of California San Francisco & 2 \\
University of Washington & 2 \\
\hline
\end{tabular}

\section{Discussion}

The top 50 most cited articles in cartilage regeneration represent the most quoted level of evidence in this field. Trends into clinical research can be graphically and visually represented through the number of citations received per annum. An article gaining increasing citation counts per year reflects an increasing trend in a specific topic. Although bibliometric studies do not represent scientific quality, an increasing trend in a subject can be considered an estimate of the standard of clinical work being undertaken worldwide.

This is of particular relevance to newly established subspecialties, whereby a transition process from established basic science articles to clinical observational studies is required.

The most cited article in our search was authored by Hollister ${ }^{10}$ in the year 2005 and received 1287 citations. The article studied "Porous Scaffold Design for Tissue Engineering."

The authors identify in their progress article the paradigm shift from using synthetic implants and tissue grafts to an engineering approach that utilizes degradable porous scaffolds integrated with biological cells for tissue regeneration. ${ }^{10}$ Here the advent of tissue engineering modalities, specifically computational topology design (CTD) and solid free-form fabrication (SFF), is

Table 5. Journals with Two or More of the Most Cited Articles

\begin{tabular}{lc}
\hline Journal & $\begin{array}{c}\text { No. of top } \\
\text { cited articles }\end{array}$ \\
\hline Biomaterials & 7 \\
Journal of Orthopaedic Research & 3 \\
Tissue Engineering & 3 \\
Biochemical and Biophysical Research Communications & 2 \\
Clinical Orthopaedics and Related Research & 2 \\
Journal of Bone and Joint Surgery, American Volume & 2 \\
Nature Materials & 2 \\
\hline
\end{tabular}

Table 6. Authors with Two or More of the Top Cited Articles

\begin{tabular}{lc}
\hline Author & Number of top cited articles \\
\hline Bruder, S & 4 \\
Caplan, A & 4 \\
Goldberg, V & 3 \\
Kadiyala, S & 3 \\
Wakitani, S & 3 \\
Barry, F & 2 \\
Fink, D & 2 \\
Freed, L & 2 \\
Guilak, F & 2 \\
Johnstone, B & 2 \\
Langer, R & 2 \\
Mao, JJ & 2 \\
Mikos, A & 2 \\
Mooney, D & 2 \\
Murphy, J & 2 \\
Vunjak-Novakovic, G & 2 \\
Yoo, J & 2
\end{tabular}

discussed. ${ }^{10}$ Integration of CTD and SFF results in scaffolds with improved mechanical properties that are required for bone tissue engineering because of the greater requirement for stiffness and strength. ${ }^{10}$ The authors postulate that these "Designer" scaffolds may lead to improved bone and cartilage regeneration, probably because of high interconnected porosity. ${ }^{10}$ The benefits of interconnected porosity are postulated to include improved cell seeding and channels to guide cell migration. ${ }^{10}$

The authors do stipulate in this article that the optimal material for regeneration has yet to be identified. ${ }^{10}$ Further, Hollister discusses the need to investigate tissue interfacing from multiple material interfacing. ${ }^{10}$ Further in vivo trials are required to help answer these questions.

This article was followed by "Chondrogenic Differentiation of Cultured Human Mesenchymal Stem Cells from Marrow" authored by Mackay et al. ${ }^{11}$ in the year 1998. This article received 755 citations.

Although Hollister primarily discusses what the composite requirements of the tissue scaffold, Mackay et al. deal with the differentiation and maintenance of biofactors. ${ }^{11}$ Here, human mesenchymal stem cells (MSCs) were induced to express the morphology of chondrocytes: the required biofactor for articular cartilage regeneration. ${ }^{11}$ Differentiation of MSCs was undertaken through exposure to a medium of $100 \mathrm{nM}$ dexamethasone as well as $10 \mathrm{ng} / \mathrm{mL}$ transforming growth factor beta(3). ${ }^{11}$ Within a fortnight of exposure to the aforementioned medium, the involved cells secreted an extracellular matrix typical of chondrogenic activity (type II collagen, aggrecan, and anionic proteoglycans). ${ }^{11}$

The authors go on to postulate that this improved understanding of chondrogenic differentiation will 
further aim to help define the mechanisms responsible for maintenance and regeneration of cartilage tissue. ${ }^{11}$

The third most cited article was undertaken in 1995 by Wakitani et al. ${ }^{12}$ The authors here studied "Myogenic Cells Derived from Rat Bone-Marrow Mesenchymal Stem Cells Exposed to 5-Azacytidine." This article predates the study by McKay et al. by 3 years. Again the differentiation of MSCs is discussed. In contrast to the study performed by McKay, Wakitani et al. discuss the differentiation of rat MSCs on exposure to 5-azacytidine. ${ }^{12}$ This compound had previously been shown to convert cells of the rat embryonic fibroblastic cell line into myoblasts, adipocytes, and chondrocytes. ${ }^{12}$ This study again identified the ability of animal MSCs to differentiate in vitro into myogenic and adipocytic phenotypes. ${ }^{12}$ Wakitani et al. suggest that MSCs in the bone marrow may be a pertinent biofactor for regenerative purposes. ${ }^{12}$

The top three cited articles were published in Nature Materials, Tissue Engineering, and Muscle \& Nerve, respectively.

The emergence of regenerative orthopedics as a new subspecialty is represented by the publication year of the top cited articles. All of the top cited articles were published after the year 1990 with the majority being published recently in the noughties with the most publications occurring in the year 2002.

We can see from our research that the bulk of regenerative orthopedic research is being undertaken in the United States, with 34 of the top 50 articles originating in the United States. Of the contributing institutions, Case Western University contributed 6 of the top 50 articles and Harvard University contributed 6 articles.

Third level universities dominate the top contributing institutions. Osiris Therapeutics Inc. is also involved as a main contributor with four top cited articles to its name.

Our search returned a considerable number of articles, 4036 in total, reflecting the largest interest in the subject; of the 50 most cited articles, the ratio of basic science articles to clinical observational articles was large, 47:3. The top cited articles were primarily basic science based with a predisposition toward cellular biology followed by tissue engineering. It can be seen from basic science data that the overall majority of the work undertaken by the science community at present was to

(a) investigate the outcome of enhanced tissue scaffolding to regenerate articular cartilage and

(b) investigate the usage of MSCs to help regenerate articular cartilage.
Overall, there are several limitations to this study. As already described, bibliometric studies do not analyze scientific quality, merely the popularity. Bias in favor of English written articles, and self-citation as well as citation omission of competitors may influence the top results.

All in all, the research currently being undertaken can potentially sculpt a pathway for observational clinical data to be performed.

\section{Conclusion}

The high ratio of basic science to clinical data reflects the need for further clinical observational trials to be performed in the area of regenerative orthopedics.

\section{Acknowledgment}

No funding source was required for this project.

\section{Author Disclosure Statement}

No competing financial interests exist.

\section{References}

1. Kelly JC, Glynn RW, O'Briain DE, et al. The 100 classic papers of orthopaedic surgery: a bibliometric analysis. J Bone Joint Surg Br. 2010;10:1338-1343.

2. Baldwin KD, Kovatch K, Namdari S, et al. The 50 most cited articles in pediatric orthopedic surgery. J Pediatr Orthop B. 2012;5;463-468.

3. Namdari S, Baldwin K, Kovatch K, et al. Fifty most cited articles in orthopedic shoulder surgery. J Shoulder Elbow Surg. 2012;12:1796-1802.

4. Murray MR, Wang T, Schroeder GD, et al. The 100 most cited spine articles. Eur Spine J. 2012;10:2059-2069.

5. Longaker MT, Chiu ES, Adzick NS, et al. Studies in fetal wound healing. A prolonged presence of hyaluronic acid characterizes fetal wound fluid. Ann Surg. 1991:4:292-296.

6. Nayak TR, Andersen H, Makam VS, et al. Graphene for controlled and accelerated osteogenic differentiation of human mesenchymal stem cells. ACS Nano. 2011;6:4670-4678.

7. Bruder SP, Kraus KH, Goldberg VM, et al. The effect of implants loaded with autologous mesenchymal stem cells on the healing of canine segmental bone defects. J Bone Joint Surg Am. 1998;7:985-996.

8. Bruder SP, Fink DJ, Caplan Al. Mesenchymal stem-cells in bonedevelopment, bone repair, and skeletal regeneration therapy. J Cell Biochem. 1994;3:283-294.

9. Bruder SP, Kurth AA, Shea M, et al. Bone regeneration by implantation of purified, culture-expanded human mesenchymal stem cells. J Orthop Res. 1998;2:155-162.

10. Hollister SJ. Porous scaffold design for tissue engineering. Nat Mater. 2005;7:518-524

11. Mackay AM, Beck SC, Murphy JM, et al. Chondrogenic differentiation of cultured human mesenchymal stem cells from marrow. Tissue Eng. 1998;4:415-428.

12. Wakitani S, Saito T, Caplan Al. Myogenic cells derived from rat bonemarrow mesenchymal stem-cells exposed to 5-azacytidine. Muscle Nerve. 1995;12:1417-1426.

13. Hutmacher DW. Scaffold design and fabrication technologies for engineering tissues - state of the art and future perspectives. J Biomater SciPolym Ed. 2001;1:107-124.

14. Kisiday J, Jin M, Kurz B, et al. Self-assembling peptide hydrogel fosters chondrocyte extracellular matrix production and cell division: implications for cartilage tissue repair. Proc Natl Acad Sci U S A. 2002;15:9996-10001.

15. Yoo JU, Barthel TS, Nishimura K, et al. The chondrogenic potential of human bone-marrow-derived mesenchymal progenitor cells. J Bone Joint Surg Am. 1998;12:1745-1757. 
16. Mo $X M, X u C Y$, Kotaki $M$, et al. Electrospun $P(L L A-C L)$ nanofiber: a biomimetic extracellular matrix for smooth muscle cell and endothelial cell proliferation. Biomaterials. 2004;10:1883-1890.

17. Murphy JM, Fink DJ, Hunziker EB, et al. Stem cell therapy in a caprine model of osteoarthritis. Arthritis Rheum. 2003;12:3464-3474.

18. Wakitani S, Imoto K, Yamamoto T, et al. Human autologous culture expanded bone marrow mesenchymal cell transplantation for repair of cartilage defects in osteoarthritic knees. Osteoarthritis Cartilage. 2002;3:199-206.

19. Peng $H$, Wright V, Usas $A$, et al. Synergistic enhancement of bone formation and healing by stem cell-expressed VEGF and bone morphogenetic protein-4. J Clin Invest. 2002;6:751-759.

20. Erickson GR, Gimble JM, Franklin DM, et al. Chondrogenic potential of adipose tissue-derived stromal cells in vitro and in vivo. Biochem Biophys Res Commun. 2002;2:763-769.

21. Kadiyala S, Young RG, Thiede MA, et al. Culture expanded canine mesenchymal stem cells possess osteochondrogenic potential in vivo and in vitro. Cell Transplant. 1997;2:125-134.

22. Kim SS, Sun Park M, Jeon O, et al. Poly(lactide-co-glycolide)/ hydroxyapatite composite scaffolds for bone tissue engineering. Biomaterials. 2006;8:1399-1409.

23. Vunjak-Novakovic G, Obradovic B, Martin I, et al. Dynamic cell seeding of polymer scaffolds for cartilage tissue engineering. Biotechnol Prog. 1998:2:193-202.

24. Li Z, Ramay HR, Hauch KD, et al. Chitosan-alginate hybrid scaffolds for bone tissue engineering. Biomaterials. 2005;18:3919-3928.

25. Cima LG, Vacanti JP, Vacanti C, et al. Tissue engineering by cell transplantation using degradable polymer substrates. J Biomech Eng. 1991;113:143-151.

26. Albrecht DR, Underhill GH, Wassermann TB, et al. Probing the role of multicellular organization in three-dimensional microenvironments. Nat Methods. 2006;5:369-375.

27. Temenoff JS, Mikos AG. Injectable biodegradable materials for orthopedic tissue engineering. Biomaterials. 2000;21:2405:2412.

28. Caplan Al, Elyaderani M, Mochizuki Y, et al. Principles of cartilage repair and regeneration. Clin Orthop Relat Res. 1997;342:254-269.

29. Yoshimura H, Muneta T, Nimura A, et al. Comparison of rat mesenchymal stem cells derived from bone marrow, synovium, periosteum, adipose tissue, and muscle. Cell Tissue Res. 2007;3:449-462.

30. Minasi MG, Riminucci M, De Angelis L, et al. The meso-angioblast: a multipotent, self-renewing cell that originates from the dorsal aorta and differentiates into most mesodermal tissues. Development. 2002;11:2773-2784.

31. Haines-Butterick L, Rajagopal K, Branco M, et al. Controlling hydrogelation kinetics by peptide design for three-dimensional encapsulation and injectable delivery of cells. Proc Natl Acad Sci U S A. 2007;19:791-7796.

32. Moutos FT, Freed LE, Guilak F. A biomimetic three-dimensional woven composite scaffold for functional tissue engineering of cartilage. Nat Mater. 2007;2:162-167.

33. Saris DB, Vanlauwe J, Victor J, et al. Characterized chondrocyte implantation results in better structural repair when treating symptomatic cartilage defects of the knee in a randomized controlled trial versus microfracture. Am J Sports Med. 2008;2:235-246.

34. Krag M, Knapp D, Nacu E, et al. Cells keep a memory of their tissue origin during axolotl limb regeneration. Nature. 2009;7251:60-69.

35. Dezawa M, Takahashi I, Esaki M, et al. Sciatic nerve regeneration in rats induced by transplantation of in vitro differentiated bone-marrow stromal cells. Eur J Neurosci. 2001;11:1771-1776.

36. Darling EM, Athanasiou KA. Rapid phenotypic changes in passaged articular chondrocyte subpopulations. J Orthop Res. 2005;2:425-432.

37. Mikos AG, Herring SW, Ochareon $P$, et al. Engineering complex tissues. Tissue Eng. 2006;12:3307-3339.

38. Rose F, Oreffo R. Bone tissue engineering: hope vs hype. Biochem Biophys Res Commun. 2002;1:1-7.

39. Freyman TM, Yannas IV, Gibson LJ. Cellular materials as porous scaffolds for tissue engineering. Prog Mater Sci. 2001;3:273-282.

40. Yang J, Yamato $M$, Kohno $C$, et al. Cell sheet engineering: recreating tissues without biodegradable scaffolds. Biomaterials. 2005;33:6415-6422.

41. Tuli R, Tuli S, Nandi S, et al. Transforming growth factor-beta-mediated chondrogenesis of human mesenchymal progenitor cells involves $\mathrm{N}$ cadherin and mitogenactivated protein kinase and Wnt signaling crosstalk. J Biol Chem. 2003;42:41227-41236.
42. Alhadlaq A, Mao JJ. Mesenchymal stem cells: isolation and therapeutics. Stem Cells Dev. 2004;13:436-448.

43. Lacroix D, Prendergast PJ. A mechano-regulation model for tissue differentiation during fracture healing: analysis of gap size and loading. J Biomech. 2002;9:1163-1171.

44. Almany L, Seliktar D. Biosynthetic hydrogel scaffolds made from fibrinogen and polyethylene glycol for 3D cell cultures. Biomaterials. 2005;15:2467-2477.

45. Glowacki J, Mizuno S. Collagen scaffolds for tissue engineering. Biopolymers. 2008;5:338-344.

46. Angele $P$, Yoo JU, Smith $C$, et al. Cyclic hydrostatic pressure enhances the chondrogenic phenotype of human mesenchymal progenitor cells differentiated in vitro. J Orthop Res. 2003;3:451-457.

47. Nakagawa $M$, Kaneda $T$, Arakawa $T$, et al. Vascular endothelial growth factor (VEGF) directly enhances osteoclastic bone resorption and survival of mature osteoclasts. FEBS Lett. 2000;2:161-164.

48. Karande TS, Ong JL, Agrawal CM. Diffusion in musculoskeletal tissue engineering scaffolds: design issues related to porosity, permeability, architecture, and nutrient mixing. Ann Biomed Eng. 2004;12:1728-1743.

49. Shah RN, Shah NA, Del Rosario, et al. Supramolecular design of selfassembling nanofibers for cartilage regeneration. Proc Natl Acad Sci U S A. 2010;8:3293-3298.

50. Reddi AH. Morphogenesis and tissue engineering of bone and cartilage: inductive signals, stem cells, and biomimetic biomaterials. Tissue Eng. 2000:4:351-359.

51. Carter DR, Beaupré GS, Giori NJ, et al. Mechanobiology of skeletal regeneration. Clin Orthop Relat Res. 1998;355:41-45.

52. Thein-Han WW, Misra R. Biomimetic chitosan-nanohydroxyapatite composite scaffolds for bone tissue engineering. Acta Biomater. 2009;4:1182-1197.

53. Lee $\mathrm{CH}$, Cook JL, Mendelson A, et al. Regeneration of the articular surface of the rabbit synovial joint by cell homing: a proof of concept study. Lancet. 2010;9739:440-448.

54. Oliveira JM, Rodrigues MT, Silva SS, et al. Novel hydroxyapatite/chitosan bilayered scaffold for osteochondral tissue-engineering applications: scaffold design and its performance when seeded with goat bone marrow stromal cells. Biomaterials. 2006;36:6123-6137.

Cite this article as: Mc Donald CK, Moriarty $\mathrm{P}$, Varzgalis M, Murphy $\mathrm{C}$ (2017) The top 50 most cited articles in cartilage regeneration, BioResearch Open Access 6:1, 58-62, DOI: 10.1089/biores.2017.0006.

$\begin{aligned} & \text { Abbreviations Used } \\ & \mathrm{CTD}=\text { computational topology design } \\ & \mathrm{MSCs}=\text { mesenchymal stem cells } \\ & \mathrm{SFF}=\text { solid free-form fabrication }\end{aligned}$

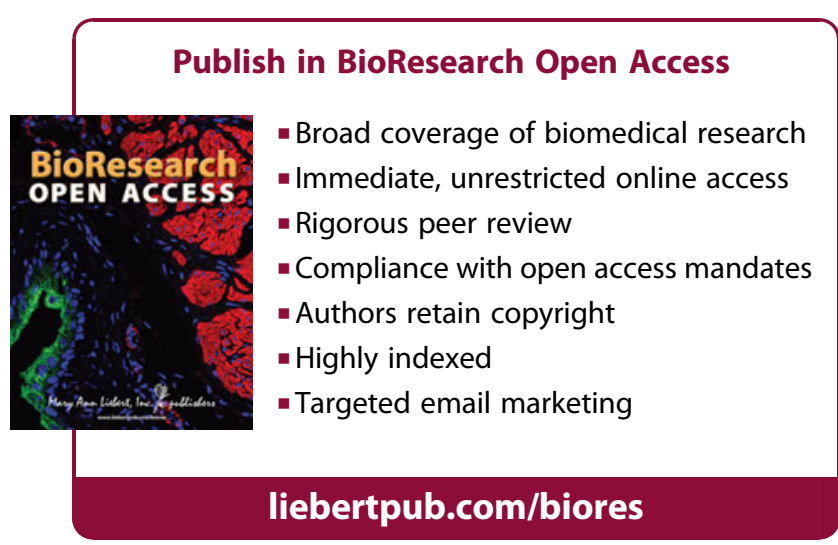

